\title{
Attrition, Retention, and Development of Early Career Teachers: Pan-Canadian Narratives
}

\author{
Benjamin Kutsyuruba \\ Queen's University \\ Keith Walker \\ University of Saskatchewan \\ Maha Al Makhamreh and Rebecca Stroud Stasel \\ Queen's University
}

\section{Authors' Note}

This work was supported by the Social Sciences and Humanities Research Council of Canada Grant.

\begin{abstract}
Our pan-Canadian research study examined the differential impact of teacher induction and mentorship programs on the early career teachers' retention. This article details the stories from our interview participants $(\mathrm{N}=36)$ in relation to what their lived experiences were during their first years of teaching and how they dealt with the requirements, expectations, and challenges. Their narratives were analyzed through the lenses of Early Career teacher attrition, retention, and development. Our findings showed that despite geographic, contextual and policy differences, there were striking similarities in teachers' lived experiences and in the impact of these experiences on their decisions to stay or leave and predispositions towards personal and professional development as teachers.
\end{abstract}

Keywords: Early Career teachers; teacher attrition; teacher retention; teacher development; teacher induction; mentoring; pan-Canadian 


\section{Attrition, Retention, and Development of Early Career Teachers: Pan-Canadian Narratives}

Good teachers are known to be a critical link to effective student learning. Teachers' qualities and abilities represent the most significant school-based factors contributing to student achievement and educational improvement (Darling-Hammond, 2006; Rivkin, Hanushek, \& Kain, 2005). Therefore, much attention must be given to the development of teachers, and especially novice teachers. New teachers' development is far from being complete upon their graduation from respective teacher preparation programs (Barrett, Solomon, Singer, Portelli, \& Mujuwamariya, 2009) and only enters into a new phase as these Early Career teachers experience transition into the workforce, become acculturated into school contexts, and encounter the complexities of professional expectations. All of these new phase experiences affect and characterize Early Career teachers' socialization (Howe, 2006; Kauffman, Johnson, Kardos, Liu, \& Peske, 2002).

Teachers choose their noble profession for different reasons. For many, this choice is coupled with desires to make a difference, to bring about positive changes, to inspire students, or to provide our societies with productive and well-educated young people (Ewing \& Smith, 2003). Yet, teaching is not an easy, nor a stress-free, occupation (Joseph, 2000), and new teachers often experience pressures and challenges during their initial inroads into the profession. In differing ways, they experience multi-layered and often complicated expectations for teaching, evaluation, and professional learning from their employers, school administration, colleagues, parents, and students (Guardino \& Fullerton, 2010; Kyriacou \& Kunc, 2007; Whisnant, Elliott, \& Pynchon, 2005). The analysis of extant literature revealed beginning teachers' stories about facing immense challenges related to the egg-crate structure of schools, isolation, reality shock, cultural adjustments, realization of inadequate resources and supports, lack of time for planning and interaction with colleagues, difficult work assignments, unclear and the inadequate expectations, intergenerational gaps amongst staff members, adverse physical, emotional, and behavioral consequences of stress, lack of orientation and information about the school system, and institutional practices and policies that promote hazing (Andrews \& Quinn, 2004; Anhorn, 2008; Johnson \& Kardos, 2002; Patterson, 2005). On the contrary, the same literature highlights stories about the purposeful, well-organized, robust, and ongoing support in the first years of teaching that can and did help novices to not only successfully overcome these tantamount challenges and stay in the profession, but also to develop and grow as professional educators.

\section{Context of the Study}

Education in Canada is a provincial/territorial responsibility. Therefore, due to the existing variations in school systems and policies, responses to attrition and retention as well as development efforts tend to be compartmentalized and contextualized to jurisdictional settings. Our multi-phase, multi-year pan-Canadian research study examined the differential impact of teacher induction and mentorship programs on the early career teachers' retention, as perceived across all provinces and territories. In addition to exploring the broader trends affecting the Canadian early career teachers, one of the research phases aimed to elicit the lived, concrete, and situated experiences of the participants through the phenomenological analysis (Van Manen, 1997) of their perceptions, descriptions, and discussions in individual interviews. In this article, we report findings gleaned from telephone interviews $(\mathrm{N}=36)$ with early career teachers from 
nine provinces and three territories. Similar to work of Schaefer, Downey, and Clandinin (2014), we studied the phenomenon of participants' stories about their experiences using narrative inquiry methodology. Because people shape their daily lives by stories of who they and others are and because they interpret their past in terms of these stories (Connelly \& Clandinin, 2006), narrative inquiry offered us a lens through which to understand teachers' thinking about their early career experiences. Using the narrative inquiry approach, we present the stories from our participants in relation to two critical questions:

- What are the lived experiences of the early career teachers across Canada during their first years of teaching?

- How do they deal with the requirements, expectations, and challenges of early career teaching?

Upon reviewing the literature with respect to teacher attrition, retention, and development, we describe our research methodology and share the qualitative analysis of the responding Canadian beginning teachers' stories. We conclude with the discussion of research results and implications for individuals and organizations that support novice teachers.

\section{Literature Review}

In this section, we briefly review literature on teacher attrition, retention of new teachers, and teacher development.

\section{Teacher Attrition}

Despite the fact that teaching is considered to be one of the helping professions, early years of teaching can sometimes be akin to a "make or break," "sink or swim," "trial by fire," or "boot camp" experience. Not surprisingly, teachers who do not feel effective or do not receive adequate support in the first years often leave schools and abandon teaching in favour of other professions (Moir, Barlin, Gless, \& Miles, 2009; Scherff, 2008). Difficult working conditions and cumbersome policies can exacerbate teacher attrition (Borman \& Dowling, 2008). In addition, exogenous factors of organizational and workforce economies are coupled with the individual factors and experiences of many beginning teachers who may be required to persist in temporary contract arrangements for a number of years before actually securing full time and regular teaching contracts. Often called the silent crisis of teaching (Rinke, 2008), attrition comes at a cost to individual teachers, schools, community and is detrimental to student learning (Guarino, Santibañez, \& Daley, 2006; Schuck, Aubusson, Buchanan, \& Russell, 2012).

Due to the lack of teaching experience and uncertain job stability, among other factors, new teachers are a vulnerable population. Teachers who examine their own vulnerabilities and then embrace these may develop their capacities as teachers, whereas others may feel that they are running the gauntlet through a dangerous obstacle course with both visible and invisible pitfalls. Therefore, despite their initial enthusiasm, many beginning teachers abandon the profession, depressed and discouraged (Boreen, Johnson, Niday, \& Potts, 2009).

Teacher attrition spans international boundaries, with data showing that many teachers quit the profession in their first two to five years; however, the attrition phenomenon is experienced globally with varying intensities (Schaefer, 2013). There are no conclusive statistics about the attrition rates in Canada; however, researchers have found that early career attrition rates vary from high to low across provinces and territories (Clandinin et al., 2012; Clark \& Antonelli, 
2009) and across certain segments of teaching profession (Karsenti, Collin, Villeneuve, Dumouchel, \& Roy, 2008; Valeo \& Faez, 2013) and findings suggest that this attrition occurs mainly within the first five years (Karsenti \& Collin, 2013). Insofar as Canadian-specific knowledge of teacher attrition, more research is needed.

\section{Retention of New Teachers}

Stemming from the above, the first three to four years after initial training are considered to be the most crucial for a teacher's decisions with respect to remaining in or leaving the profession (Jones, 2003). A growing consensus acknowledges the value of some kind of support for beginning teachers to help mitigate the issue of attrition (Le Maistre, Boudreau, \& Paré, 2006). Given the fact that many new teachers make tremendous improvement during their first years of teaching, then the attrition issue is not best addressed by new recruitment but, rather, by retention of high-quality teachers and by teacher development (Farrell, 2012). Clandinin et al. (2012) further urged our increased focus on how to sustain new teachers throughout their teaching careers, rather than upon merely retaining them in the profession.

Teacher induction is a long-term, comprehensive, coherent, and sustained professional development process, organized by a specific jurisdiction to acculturate, train, support, retain new teachers, and help them develop a lifelong learning program (Wong, 2004). It takes a long time for teachers to develop their identities as teachers, which in turn affects their development (Brindley \& Parker, 2010). Most often, mentorship is an integral and crucial component of induction programs, intended to support individual beginning teachers' needs (Hobson, Ashby, Malderez, \& Tomlinson, 2009).

We know that mentoring programs do not benefit all teachers (Towers, 2012); however, we also know that strong induction programs and high-quality mentoring programs have positive impacts through increased teacher effectiveness, stronger self-confidence, higher levels of satisfaction, motivation, and commitment, reduced stress, improved classroom instruction and student achievement, and early career retention of novice teachers (Glazerman et al., 2010; Guarino et al., 2006; Henry, Bastian, \& Fortner, 2011; Ingersoll \& Strong, 2011; Wynn, Carboni, $\&$ Patall, 2007). Furthermore, new teachers who see themselves as more efficacious are more likely to remain in teaching than those who do not (Swanson, 2012).

Having supportive school leaders is also essential for long-term sustenance of beginning teachers (Bickmore \& Bickmore, 2010). School administrators' commitment to the development of new teachers either supports and promotes the retention of novice teachers or undermines the success of induction and results in teacher attrition (Jones, 2002; Wechsler, Caspary, \& Humphrey, 2008). Equally important are interpersonal supports (Friedrichsen, Chval, \& Teuscher, 2007) and organizational climates that enable trusting relationships between teachers, students, and school leaders and set the stage for a safe, thriving learning environment (Tschannen-Moran, 2009). A supportive and encouraging school culture appears to be a critical variable for helping new teachers to cope with the rigours and challenges of their new careers (Schuck, Brady, \& Griffin, 2005).

\section{Teacher Development}

Sustainable development of novice teachers has the potential to increase the quality of teaching and improve learning experiences in schools. However, there is little research that 
focuses specifically on teacher development with respect to beginning teacher attrition and retention; this sparsity exists despite the fact that professional learning is often part of the research on induction, mentoring, and collaboration with colleagues (Schaefer, Long, \& Clandinin, 2012).

Lovett and Cameron (2011) suggested that three categories of conditions have impact on the effectiveness of early-career teacher learning: "cultures that promote conversations about learning and teaching, structures that make it possible for teachers to have these conversations, and the roles that more experienced teachers play in hindering or promoting the professional learning of early-career teachers" (p. 90). Researchers have indicated that teacher eagerness for professional development is greatest in schools that made both formal and informal learning an integral part of the teachers' work (Sprinthall, Heiman, \& Thies-Sprinthall, 1996). Ultimately, mentoring, whether formal or informal, has personal learning of the protégé as its primary goal (Lankau \& Scandura, 2002; Portner, 2008). However, sometimes beginning teachers may be reluctant to make informal approaches to colleagues because they fear that they may come across as incompetent (Kyndt, Gijbels, Grosemans, \& Donche, 2016).

Undertaking self-initiated professional learning activities is also an important aspect of teacher development (Kwakman, 2003). It is important for novices to eventually replace dependence on mentors and colleagues with increasing self-reliance in order to enhance reflective thinking, develop deeper problem analysis skills, and widen repertoire of strategies (Brock \& Grady, 2006). Researchers have shown that when teachers demonstrate a high level of ownership over their own learning, they then decide what they will learn from what their workplaces offer them (Admiraal et al., 2016). Different phases of self-directed learning processes can be distinguished, but they generally include a needs assessment, planning, engaging in learning, and evaluation (Knowles, Holton, \& Swanson, 2015).

Generative relationships contribute to the positive school climate and are a critical means through which new teachers can develop. Relationships are viewed as the backbone of the teaching profession and often associated with the foundations of schools' success (Bryk \& Schneider, 2002); hence, new teachers need to develop and maintain multidimensional relationships in schools in order to develop. Relationships with peers have been found to help beginning teachers with socialization into the teaching profession and professional growth (Achinstein, 2006; Friedrichsen et al., 2007; Nasser-Abu Alhija \& Fresko, 2010; Tillman, 2005). Trust is viewed by some researchers as the most important feature of a supportive school climate (Dempsey \& Christenson-Foggett, 2011; Donne \& Lin, 2013). Moreover, positive teacherstudent relationships (Razer \& Friedman, 2017) and teacher-school administrators relationships (Moolenaar, Daly, \& Sleegers, 2012) are pivotal for new teachers' development.

\section{Our Methodology}

This article details the qualitative interview phase of a multi-year, pan-Canadian research project that examined the differential impact of induction and mentorship programs on early career teachers' retention across the provinces and territories. As noted above, for this phase we have adopted a narrative inquiry framework (Clandinin \& Connelly, 2000) to analyze the stories and insights that Canadian early career teachers shared with us to explain their particular experiences and perceptions. As Connelly and Clandinin (2006) noted, narrative inquiry is the study of experience as story, which "as a methodology entails a view of the phenomenon. To use 
narrative inquiry methodology is to adopt a particular view of experience as phenomenon under study" (p. 375). We attempted to analyze simultaneously three commonplaces of narrative inquiry-temporality, sociality, and place-to uncover the complexity of the relational composition of participants' lived experiences both inside and outside of an inquiry as well as to imagine the future possibilities of their lives (Clandinin \& Huber, 2010). This approach allowed us to explore the narratives through the past-present-future continuum, focusing on relationships and interactions and situating them in a particular context (Craig, 2014). To this end, we framed our interview questions using a strengths-based, positive development approach of an appreciative inquiry (Cooperrider \& Whitney, 2007; Tschannen-Moran \& Tschannen-Moran, 2011).

\section{Research Sample}

We selected our interview participants from an online survey participant sample (an earlier research phase) who had expressed their willingness to participate in the follow-up interviews. The online Teacher Induction Survey was developed by the researchers, based on suggestions and recommendations from an expert panel of researchers and practitioners, the relevant literature, and adapted items from related instruments. The invitation to participate in the online survey for new teachers within their first five years of employment in a publicly funded school in Canada was widely distributed through various venues (e.g., teacher associations, ministries, community organizations, social media), across all provinces and territories in the springsummer of 2016. With various degrees of completeness, the researchers received over 2000 responses to the survey from all Canadian jurisdictions. From the survey sample, we randomly selected participants with the purpose of pan-Canadian representation. We conducted telephone interviews with 36 teachers from nine provinces and three territories in Canada (33 in English, 3 in French; see Table 1 for participant demographic information).

Table 1

List of Participants

\begin{tabular}{|l|l|l|l|l|l|l|}
\hline$\#$ & Pseudonym & Province/Territory & Language & Gender & Age & Teaching Experience \\
\hline 1 & Mike & NS & English & Male & 33 & 5 years \\
\hline 2 & Lise & ON & French & Female & 26 & 2 years \\
\hline 3 & Maira & NL & English & Female & 27 & 5 years \\
\hline 4 & Kamille & ON & French & Female & 26 & 3 years \\
\hline 5 & Mackenzie & ON & English & Female & 24 & 2 years \\
\hline 6 & Evelyn & AB & English & Female & 26 & Less than 1 year \\
\hline 7 & Kandace & AB & English & Female & 31 & 2 years \\
\hline 8 & Alli & QC & English & Female & 26 & 2 years \\
\hline 9 & Stewart & SK & English & Male & 29 & 4 years \\
\hline 10 & Nick & SK & English & Male & 27 & 3 years \\
\hline 11 & Ashish & NT & English & Male & 32 & 1 year \\
\hline 12 & Charlotte & AB & English & Female & 38 & 4 years \\
\hline 13 & Maribelle & SK & English & Female & 39 & 1 year \\
\hline 14 & Christina & ON & English & Female & 24 & 1 year \\
\hline 15 & Andrea & ON & English & Female & 28 & 3 years \\
\hline 16 & Mark & AB & English & Male & 31 & Less than 1 year \\
\hline
\end{tabular}




\begin{tabular}{|l|l|l|l|l|l|l|}
\hline 17 & Ken & ON & English & Male & 26 & 3 years \\
\hline 18 & Lily & NS & English & Female & 24 & 2 years \\
\hline 19 & Lois & NB & English & Female & 27 & 3 years \\
\hline 20 & Myles & MB & English & Male & 25 & 2 years \\
\hline 21 & Cassie & MB & English & Female & 51 & 3 years \\
\hline 22 & Gladys & ON & English & Female & 49 & 5 years \\
\hline 23 & Tennae & BC & English & Female & 49 & 4 years \\
\hline 24 & Anya & NU & English & Female & 24 & 1 year \\
\hline 25 & Ruth & ON & English & Female & 33 & Less than 1 year \\
\hline 26 & Edward & ON & English & Male & 42 & 3 years \\
\hline 27 & Shana & NU & English & Female & 46 & 5 years \\
\hline 28 & Jane & NU & English & Female & 36 & Less than 1 year \\
\hline 29 & Marilyn & YT & English & Female & 32 & 5 years \\
\hline 30 & Noor & BC & English & Female & 34 & 4 years \\
\hline 31 & Helen & BC & English & Female & 28 & 4 years \\
\hline 32 & Alessandra & BC & English & Female & 41 & 2 years \\
\hline 33 & Barbra & BC & English & Female & 55 & 4 years \\
\hline 34 & Lebert & BC & English & Male & 34 & 5 years \\
\hline 35 & Shelle & BC & English & Female & 29 & 3 years \\
\hline 36 & Françoise & ON & French & Female & 27 & 3 years \\
\hline
\end{tabular}

\section{Data Collection and Analysis}

Most of the interviews lasted approximately 20 minutes. The interviews were recorded and transcribed verbatim, with all proper names and identifiers removed and changed to pseudonyms. Participants' stories were compiled by the researchers and analyzed both deductively and inductively following standard coding processes for etic and emic approaches to data analysis (MacMillan \& Schumacher, 2006). Five open-ended questions, pertaining to teacher experiences with development, resilience, mentorship, and leadership in schools, served as the initial organizing framework for the responses. We have used a sociological approach to the narrative inquiry analysis of told stories with a focus on specific aspects of early career teachers' lives (Chase, 2005). Subsequently, the emergent codes were established according to the recurring themes. Both etic and emic codes were then combined into categories, and categories into patterns or concepts (Lichtman, 2010).

\section{Research Findings}

The rich narrative data are presented below with select direct quotes from participants in relation to the themes of retention and attrition of new teachers and of teacher development.

\section{Retention and Attrition of New Teachers}

When asked to share a significant story or moment that played a part in convincing them to remain in the profession, from their first years of teaching, interviewees discussed internal and external factors for staying and for leaving. These descriptive factors usually entailed a circumstance, situation, fact, or influence, or a combination of these, which contributed to a certain result or outcome in their teaching careers. Inductively, we surmised that the intrinsic 
factors had to do with personal values, motivation, thoughts, feelings, and beliefs, whereas extrinsic factors were related to structures, processes, or other individuals outside of the personal realm that exerted significant influences on the teachers' decisions. Below, we have grouped the stories according to the type of influence.

Intrinsic factors for retention. Passion for teaching was the most frequently mentioned intrinsic factor that had encouraged teachers to stay in the profession. A strong intrinsic motivator that kept teachers going, a passion to teach was often threatened by circumstances, especially for the occasional teachers who were still without fulltime contracts. Ken suggested that passion wins if teachers "remain patient." For Ruth and Shana, the passion for teaching was perennial: they always wanted to teach and still do.

The internalized value of supporting students and the positive impact that teachers can have on students encouraged teachers to persevere. Barbra, Jane, Lois, Tennae, and Ashish described a sense of raison d'être that comes from having a positive impact upon students. For example, Tennae said, "The convincing [factor] to stay is the student achievement; when students, particularly at-risk or high-risk kids, have breakthroughs or stay in school for that matter, that is-that is significant to me."

Myles and Françoise experienced mutual support-teachers supporting their students and students affirming their teachers-which motivated them to persevere. Françoise reflected on students with special needs. She described her work with a group of students that no one wanted to teach because they had difficulties with learning. She persevered through many obstacles, ranging from the demands of her class to a lack of structural supports, and was determined to create bonds with her students. On her birthday, the students hid under the stairs in order to bring her a cake and sing happy birthday. At that moment, Françoise realized that she gave them a challenge and a desire to learn, and that was the biggest affirmation for her.

Experiencing tangible student learning in and through a challenging context appeared to have fuelled new teachers' passion. Lois described her experience:

It made me believe in being a teacher to see a student who, when I first arrived, was having a very difficult time, didn't want to interact as much because he didn't want to say something wrong but then was starting to take more risks by the time I left that classroom, and it was just an amazing - it really made me think I want to stay in this profession - this is why I'm doing this profession.

Lily experienced a similar boost in motivation from observing positive shifts in student attitudes:

The youth would often say, "I can't do this." And the youth has become a leader in helping other kids believe in themselves and say, "I'm having a hard time, but I can try instead of I can't." And, yeah. So, that's been a big motivator to continue teaching and continue working with youth.

Cassie, Kandace, and Anya all commented on the motivational boost they had received from positive student feedback. When a teacher recognizes that she has been helpful to a child, it can be profound. Cassie shared, "I had a suicidal student, for example. That was a big one, and I recognized it and talked to him about it and then got him to some help. In moments like that, you wonder-if I hadn't, would, in fact, anybody have noticed?" 
In similar vein, Myles experienced positive feelings of enjoyment when children expressed their appreciation to him: "There are some nice moments, like when kids give you things, or they come up and they say oh, you're my favourite teacher ... I feel relaxed and confident in my skills, and that's always a nice feeling." Lise observed students learning something new, demonstrating curiosity, a desire to learn, and being happy in class; it was moments like these that kept her in teaching. Positive mindset, proactiveness, and patience have been encouraging factors for new teachers to stay in the profession, keep going, and involved in professional development.

Extrinsic factors for retention. Factors that encouraged teacher retention included mentoring relationships; receiving support, encouragement, empathy, appreciation, and positive feedback; and a positive school climate. These factors were further highlighted when teachers were faced with difficult situations.

Support that helped these new teachers came in many forms. The most frequent supports cited were formal or informal mentoring relationships. Other helpful supports came from principals, school leaders, colleagues (both retired and working, including other new teachers), students, classmates, union representatives, friends, family and community members. Strong relationships and supports encouraged teachers to persevere and to overcome barriers encountered in their early years of teaching. For instance, Noor found that making connections and receiving mentorship kept her going. Christina credited her mentor for sustaining her through periods of feeling overwhelmed and unwell. Without her mentor, she said, "I don't think I would have stayed in teaching for very long." Nick expressed gratitude for a retired teacher who had stepped into guide and supervise his work during a period of procedural fluctuation at the school board. He appreciated support in the larger context of what he called "an awful lot of negative feedback."

Edward shared that the support he had received from his principal had encouraged him not to quit. He was filling in for a teacher "who went off on a stress leave again" from working with a very challenging class. One day, Edward was frustrated at a challenging situation that happened in class, and considered quitting this "whole supply teaching business," when the principal stopped by to affirm his work. Edward added that the most positive moments of his job were the supports received from people who were in his school.

Marilyn had initially decided to leave teaching, based on an unsupportive environment where collaboration was rare and the lack of motivation was prevalent. The negative climate threatened her motivation to stay. Rather than leave the teaching profession altogether, she moved to another province. There, she had experienced a positive, collaborative school climate where colleagues were "in the habit of helping and you can bounce ideas off them." Marilyn noted that her lifestyle improved. She spent more time outdoors with her students and was supported by the community.

Intrinsic factors for attrition. We interviewed one teacher who had already left the profession (Andrea), and two who were preparing to leave (Alessandra and Nick). Despite the fact that only three teachers in our sample represented attrition decisions or inclinations, and this number might seem small, we found their shared stories to be powerful and have significant implications for their personal and professional lives. Moreover, their narratives were also indicative of intentions that many other interviewed teachers had in the past, inducing them to 
consider leaving the profession, especially at times of great stress. Although those teachers had not made the decision to leave, their stories add to our understanding of potential internal and external influences for attrition.

Having to personally deal with high levels of stress and anxiety as a result of conflicting job demands, unsupportive parents, and administration were noted as factors leading teachers at all career stages towards leaving the profession. Andrea was 28 years old and in her third year of teaching. At the time of the interview, she had just left teaching because of tremendous stress, and shared with us some of the grief in her story:

I left a permanent teaching job, which is difficult to get in Ontario, but I was very unhappy. So, I think the research you're doing is important because figuring out why new teachers leave the career I think can help with retention.

The combination of intrinsic and extrinsic conditions prompted her to leave teaching, as her well-being deteriorated, and her sense of happiness decreased: "I was heavily involved with coaching; putting in 60 to 80 hours a week just took a toll on me." Another teacher, Alessandra, who was in the final stages of preparing to quit the teaching profession, shared about occasional feelings of having a positive impact on students, yet, she added that they "generally have not overridden the stress and difficulty that [she] faced as a new teacher."

Nick, 27 years old and in his third year of teaching, was planning to leave teaching for another helping profession. He shared about working extremely hard in his first years as a teacher, to the point of even starting to neglect his family, due to incredible stress and impossible demands placed upon him by other teachers and principals alike: "The anxiety piles up, because, no matter what you do, there's always something more they wanted." Nick desired support to help navigate the challenges, but instead went unsupported, burdened with responsibility: "It always falls back on me, so that this differentiation and adaptation is great and ideal but what's happened is it shifted responsibilities to the point where there is a never-ending well of responsibility on the teacher." Nick observed high colleague attrition around him: "I see more and more teachers who are in their 40s or 50s quitting and picking up a different job.... No teacher quits because they don't like the job, but because they're stressed or overworked. Teachers are a certain type of personality and that personality profile is a high achieving, pleasing personality."

Dealing with stress was noted by others, who had thought about leaving at some point in their early career. For Alli, stress was a hint at potential withdrawal, but she found help and recommended that teachers do not pretend to be okay if they are not. She suggested that new teachers should find "at least one person at the school, I think, that you can hopefully talk to."

Extrinsic factors for attrition. The key external contributors for Andrea were related to the facts that the school lacked structure and discipline, class sizes were constantly getting bigger, and demands were increasing. Lack of a supportive system was the main factor attributed to teachers becoming frustrated enough to consider leaving their profession. Another important story came from Alessandra, who is a 41-year-old teacher and in her second year of teaching. She shared her frustration clearly and said:

I heard when I went to the teachers' college that ... 50 per cent of teachers didn't stay in the profession, and I thought, well, that's impossible ... I thought what would be difficult 
was the kids, working with the kids, and sometimes the parents. And the kids are the best part of it. It was everything else that was at play ... We're dealing with large class sizes, class composition that's not manageable, major lack of supports within the system. And so, when you combine that systemic problem with a localized problem of a very difficult administrator, it just becomes impossible.

Some participants mentioned observing other teachers dropping out of the profession because of certain provincial regulations that are restrictive to new teachers securing permanent jobs. Several teachers from Ontario and Nova Scotia critiqued regulations affecting new teachers. For example, Ken discussed the impact of Ontario's Regulation 274, which mandates that teachers be hired for permanent jobs based strictly on seniority and not on merit:

I really adamantly think that the regulation is not doing what it was intended to do. It, in fact, is hurting the teaching profession more than it's helping it, because nepotism still exists, the need for teachers to improve their skills is no longer there, and great, fantastic teachers that I know are leaving the profession.

Related to this perception of constricting regulations, Gladys explained that if novice teachers are frustrated and lack "passion ... then they should consider other employment." Stewart hoped to find employment in Ontario but moved to Saskatchewan in order to teach full-time. He advised new teachers to "be prepared to leave Ontario for the next decade, because the way the regulations are set up, the deck is extremely stacked against you."

\section{Teacher Development}

We asked our participants to think back over their experiences in their first years of teaching and tell us what had worked best for them vis-à-vis their development as teachers. Their perspectives revealed three main sources that had helped in enriching their development: formal and informal learning from others, collegial school climate, and, self-learning.

Informal and formal learning from others. Similar to the positive role of mentoring relationships on teachers' retention, formal and informal mentoring was the most frequently mentioned factor that was important for teachers' professional growth. Christina explained:

In my first year of teaching, what I found worked best for my development was just having a mentor teacher there to ask questions pretty much whenever I needed to, and somebody with a lot of research that were willing to share those resources.

Evelyn expressed her appreciation for mentoring and said:

I really appreciated having one-on-one time with a mentor or another teacher. Having somebody to bounce ideas back really benefited me to expand my understanding and just to gain confidence in the decisions that I was making.

Shelle highlighted similar beneficial experience from formal mentoring: "Initially one-onone time with someone in the district to orient me to how everything worked was the best possible practice for that experience." Others informally found co-workers knowledgeable, versed in research, and most importantly willing to share those resources. As Anya explained, "They weren't assigned or anything, but they kind of took me under their wing and really helped me out with procedures, and, if I had any difficulties or any questions, I would usually go to 
them first."

The participants also described co-teaching as an exceptional learning experience, wherein they were able to co-teach, co-plan, and explore things they planned to do in the classrooms. For example, Evelyn noted, "that kind of co-teaching and co-planning was awesome ... [my mentor] let me kind of explore things I wanted to do, but he was there as kind of support."

Getting help from more experienced teachers was not the only source of help that novice teachers valued, they also expressed how their interactions with other new teachers allowed them to feel that they were not alone in the challenges and facilitated their meaningful engagement in informal professional learning and formal professional development activities. Noting that working in a school board that supported new teachers was a big difference for her professional growth, Ruth noted:

About four times a year we would get together as new teachers, and you know, talk about what we were doing in the classroom. We would talk about things like learning how to write proper report card comments, sort of classroom dynamics, special needs in the classroom, things that as new teachers we might not have had a lot of experience with before.

Shana suggested, "It was good to be able to do professional learning in the school while I was actually working, because, you know, you can actually apply it and 'work it' so that it fits with your students and your community, your classroom."

Collegial school climate. Generally speaking, school climate that entailed collegial relationships between new teachers and colleagues, administrators, and students, allowed beginning teachers to excel in their development. Experienced teachers played vital roles in the transitions of novice teachers. Good rapport promoted collaboration and sharing materials among colleagues where interviewees felt supported and encouraged to ask for help when needed; both were seen as results of the healthy relationship they had managed to establish in their schools. The kind of relationships that some of our participants had developed with other teachers, some of whom ended up playing the role of informal mentors to them, enabled the space for informal dialogues with more experienced colleagues. When things did not go well for them, the novice teachers noted that their need for space and the opportunities to share their frustrations were limited. Under these circumstances, experienced teachers were there to provide novices with practical advice and help.

At the same time, participants also emphasized the importance of collegial relationships and networking with other new teachers. Christina elaborated:

In my school, there were also a lot of first year teachers, too. It was very helpful, not just having everybody who knew what they were doing and not everybody that was always giving me advice, but there are also teachers in the same boat as me ... I know there's a big emphasis on setting up the network of mentor teacher to new teachers, but I think it would be really great, too, to have just networking in terms of new teachers and sharing what's gone well and what hasn't gone well.

Along with colleagues, Ashish explained the importance of developing a collegial relationship with principals or vice-principals as an asset in his early teaching years. He portrayed his principal as being patient, sympathetic, and someone who explained things well. 
Others also noted that teachers need supportive principals in order to build beneficial relationships with them. Good relationship with administrations facilitated their professional development. Marilyn explained, "I work with the administration who is very open to professional development opportunities. If an opportunity comes up, then they're very willing to pay for a sub, and then I can go and do the PD." Moreover, good relationships with administrations facilitated teachers' relationships with parents. Christina noted, "I had to make a few uncomfortable phone calls [with parents], and she [the principal] was very supportive about practicing what I could say and making sure that I came off in the most professional way." Likewise, Evelyn liked her vice-principal's proactive approach since he had guided her on how "to properly answer emails or phone calls. If I ever had to phone home for a parent, he said he could be there, with me just to be giving me tips and stuff, so I think that was great."

Finally, having good relationships with students emerged as a significant developmental aspect for some of our interviewees. Several teachers noted the importance of being patient with students and maintaining a teacher/student relationship that was based on mutual trust and respect. Françoise explained that the relational aspects of teaching were the main reasons why she had chosen this profession in the first place. In her practice, she had benefitted most from good relationships and strong bonds with colleagues, the department, and students.

Self-learning. Participants' development also entailed self-learning, based on dedicated reflection time, acquiring or nurturing a proactive mindset, gaining classroom experiences, and from independent work that aims at developing knowledge and skills. Some interviewees described reflection as their best mechanism for improvement. Edward explained:

The best thing for development, I think, is reflection. You have to go through difficult times, you have to go through good times as a teacher, and you have to be able to think back and mentally prepare differently for the next time.

However, it was unfortunate to hear that while some of these teachers valued reflection as an effective technique to progress, others said they had faced the challenge of not having enough time to reflect. Charlotte described it well, saying, "There isn't enough time... especially not enough time to reflect properly on what you're doing. There's only enough time to just survive from day to day, but I don't think there's enough time to improve." In a number of cases, possessing a proactive mindset had allowed early career teachers to plan ahead and to be flexible. For example, Ken highlighted the following:

What worked best for me was being very proactive in taking advantage of every opportunity, and really being flexible ... I think my mindset was just to be very proactive, to be very flexible, and to be willing to do anything, because anything could eventually lead to something.

Other interviewees highlighted the importance for new teachers to be good planners, especially when preparing their curriculum outcomes. They shed light on the development that comes with experience in the classroom. As Myles noted, "To be honest with you, the development probably just comes with the experience in the classroom ..." Stewart valued the hands-on experience in class:

I would say the best thing that worked best for my development as a teacher was falling off the horse once or twice. I was given a pretty difficult classroom my first go-around. It was 
a grade eight-nine split of $36 \mathrm{kids}$, and there were moments where my planning was insufficient to handle that, and rather than just being cast aside and having the next person in line, I was able to kind of figure that out on my own and figure out what adjustments I needed to make.

Nick echoed Stewart's experience and said:

What worked best? You almost had to try things and see if they would work because, no matter how much you attempted things that you were taught how to do, the trial by fire was really what sort of set them to-like, they'd work or not in a way.

Some participants shed light on their independent work that had consisted of such activities as volunteering, attending workshops, acquiring knowledge through reading and by pursuing further qualifications. Gladys explained:

I felt encouraged to know that there are different ways of doing the same thing and doing it well, if that makes any sense. And sometimes you find that out from learning and reading and taking courses, and sometimes you find that out just from talking with other colleagues.

Anya described the profession as a self-directed one and said:

For new teachers or to people coming into the profession, it's very self-directed profession, depending on your principal, but it really can be in that you need to find your resources, you need to look for things that will help you, and you know, there's always ways you can find that.

Teachers found publicly available internet resources, as well as those shared on social media groups (e.g., Facebook, Pinterest, etc.), to be the most helpful.

\section{Discussion: New Teacher Experiences}

The generous insights from the stories shared with us through the interview process of a crosssection of early career teachers across Canada, enriched our learning about their experiences and ongoing pursuits. Although not generalizable to a broader population of new teachers, our qualitative findings corroborate and add to the extant literature on early career teaching in Canada. Chiefly, the factors affecting teacher development, teacher retention and attrition, as well as some specific yet common needs that new teachers require in order to thrive, are presented in our findings. The pan-Canadian narratives show that despite geographic, contextual, and policy differences in the lived experiences of our participants, there were striking similarities amongst the many teachers' experiences. We also noticed the common impact of these experiences on their decisions to stay or leave and predispositions towards personal and professional development as teachers.

\section{Intrinsic and Extrinsic Influence on Retention and Attrition}

According to their narratives, new teachers' experiences were significantly affected by intrinsic and extrinsic factors that were either influencing their decisions to stay in or to leave the profession. 
Retention factors. Teaching is a demanding profession that requires tremendous energy, commitment, and resilience. The predominant intrinsic influence for retention for our participants was the high level of passion that teachers felt for their profession, especially manifested through the strong desire to help students thrive. When teachers felt successful, they were affirmed in their choice of profession, suggesting a harmonious type of passion that increases adaptability (Carbonneau, Vallerand, Fernet, \& Guay, 2008). For new teachers, cognition of available supports contributed to pride in their work, a sense of purpose and positive impact, and feelings of personal satisfaction. Positive affirmation, perseverance, and motivation to continue for novice teachers in our study stemmed from omnidirectional support system consisting of peers, administration, parents, and even students, which is critical for capacity building in early career teachers (Clark \& Byrnes, 2012). Overall, personal confidence and efficacy is built on supportive relationships that help beginning teachers with socialization into the teaching profession (Fenwick, 2011; Long et al., 2012; Tillman, 2005). According to many teachers interviewed, being supported helps to maintain a positive mindset, which is critical in face of the numerous challenges in early years teaching.

The most frequently cited extrinsic factors influencing teacher retention pertained to formal and informal supports from people and structures in education that had helped, guided, shared, and assisted in professional and interpersonal ways. The beneficial role of mentors was prevalent, supporting the value of formal mentorships as part of new teacher induction processes (Ingersoll \& Strong, 2011). The quality of the interpersonal relationship between mentor and mentee affirms that "the value of having a mentor teacher depends greatly on the mentor" (Andrews \& Akerson, 2012, p. 10). Not all of our interviewees experienced a formal mentorship, and even some who did, chose to seek the support of informal mentor and peer connections, especially in difficult times and through sharing of resources. Liston, Whitcomb, and Borko (2006) found that emotional support from more experienced colleagues can determine whether teachers stay in teaching and what kind of teachers they become. Elfers, Plecki, and Knapp (2006) noted that support for professional learning through incentives and access to resources was of importance in retaining teachers in schools with high rates of poverty. Finally, when novices felt supported by their principals, and not at risk of reprisal or termination, they felt safe to experiment in their craft in order to master it. The supports of school leaders can be highly influential in establishing a positive school culture (Certo, 2005; Schuck et al., 2005), which enhances efficacy in both teachers and students (Ross \& Gray, 2006) and has a positive effect on teacher retention (Brown \& Wynn, 2009).

Attrition factors. In contrast, teachers frustrated by personal and systemic obstacles within the profession spoke of leaving. Challenges new teachers face "may be thwarted and result in collapse when they become overwhelming," impeding resilience and "ability to adapt to difficult situations" (Ewart, 2009, p. 475). We noted that a lack of support resulted in some teachers battling stress and anxiety over daily school events. Similar to others, we found that when administrators are unresponsive to teachers' needs, their emotional health is affected and their sense of isolation and frustration increases (Brindley \& Parker, 2010; Cherubini, Kitchen, \& Hodson, 2008; Frels, Zientek, \& Onwuegbuzie, 2013). Neglecting personal well-being may take a toll, as many of the interviewed new teachers had learned the hard way. Therefore, self-care is critical for new teachers due to its focus on maintaining a positive mindset and committing to reflective practices (Wood \& Stanulis, 2009). Sometimes, the opportunity to have a frank conversation about these issues was found helpful to beginning teachers. A teacher (Andrea), 
who had already left her teaching position, was thankful for the opportunity to speak with us, in hopes that her message might get out and that conditions for new teachers might improve in the future.

Increasing and unclear demands, lack of resources, insufficient support and inconsistent communication, all have a cumulative effect upon teachers who feel ineffective and quit as a result (Moir et al., 2009). When new teachers face challenges from the external environment, interpersonal supports are most impactful (Friedrichsen et al., 2007). Personal challenges, lack of support, and policy and legislation obstacles dramatically affected new teachers in our sample, leading one to leave their profession, two to get ready to leave, and several more to contemplate leaving. Unfortunately, the stress of trying to become an effective teacher without receiving adequate support leads many teachers to seek supportive environment elsewhere (Harris, 2015). We contend that if the external stressors continue without sufficient positive influence to mitigate them, teachers may give up. Those among our participants who reached this stage, experienced great frustration at their insurmountable obstacles and grief over a passion for teaching snuffed out. Beyond the direct role in coordination and establishing of induction and mentorship structures, we agree with other scholars that school leaders have an indirect impact on teacher attrition by nurturing supportive school climate (Bickmore \& Bickmore, 2010; Catapano \& Huisman, 2013; Cherian \& Daniel, 2008). Deeper inroads into the leaders' impact lie within the systemic culture of a school or school board, which may or may not endorse the cultivation of positive school climate and trusting collegial relationships.

\section{Teacher Development}

Three main sources had helped teachers in elevating their professional development: formal and informal learning from others, focus on self-learning, and collegial school climate.

Formal and informal learning from others. Effective teacher development efforts include formal support through structured programs as well as opportunities to talk more informally as the need arises on a day-to-day basis (Lovett \& Davey, 2009). Having a mentor, both formally and informally, was the most frequently cited factor necessary for the new teachers' development in our study. Mentorship support for new teachers is considered a "musthave resource" (Glazerman et al., 2010; Guarino et al., 2006; Henry et al., 2011; Ingersoll \& Strong, 2011). One-on-one time with a mentor or another teacher had allowed them to expand their understandings and gain confidence in their everyday decisions. For new teachers, making independent decisions could be one of the most challenging tasks; with no prior experience, they might feel vulnerable or hesitant to make choices. Having a mentor, formal or informal, helped some of our participants make decisions with assurance, thus increasing their self-efficacy (Fantilli \& McDougall, 2009; Tschannen-Moran \& McMaster, 2009). For our participants, mentors exhibited positive impact on their learning by being knowledgeable, competent, and willing to guide, enable, and share resources. These characteristics align with the main roles of new-teacher mentors found in the literature: (a) guiding, leading, advising, and supporting; (b) coaching, educating, and enabling; (c) organizing and managing; and (d) counselling and developing interpersonal relationships (Harrison, Dymoke, \& Pell, 2006).

Our findings also suggest that collaboration made a positive impact on our participants' growth and development. Nieto (2003) argued that collaboration is vital if new teachers are to solve the problems of their practice because collaborative discourse allows teachers to build 
critical and long-standing relationships with colleagues, which in turn, produce a sense of community. For our participants, co-teaching, co-planning, and asking for help were remarkable learning experiences in which they were able to incorporate what they learned into their own classroom practices. Similarly, researchers found that a mentoring environment based on collaboration and co-teaching allows novice teachers to become reflective thinkers and colearners (Hatton \& Smith, 1995; Kochan \& Trimble, 2000). Furthermore, Eberhard, ReinhardtMondragon, and Stottlemyer (2000) maintained that induction and mentoring programs designed to develop a reflective teacher enhanced more rapid movements for new teachers along the learning continuum from survival to maintenance to impact. Therefore, it is necessary to capitalize upon the fact that teachers collaborate more at the beginning of their career, when they have higher motivation and eagerness for learning from, and drawing on, the professional expertise of more experienced teachers (Richter, Kunter, Klusmann, Lüdtke, \& Baumert, 2011).

Our findings highlight the importance of having formal professional learning and professional development activities that fit the needs of early career teachers. Not all of our participants were fortunate to have the professional development opportunities that met their needs. Darling-Hammond and Richardson (2009) suggested the need for revision of teachers' professional development to satisfy the learning needs of teachers in relation to three areas: content, context, and design. They maintained that the content of teachers' professional learning needs to be centered on student learning and involve active teaching, assessment, observation, and reflection rather than abstract discussions. Context should integrate teacher learning with school improvement and design should be active and sustained for greater teachers' engagement. Similarly, Campbell (2017) highlighted the importance of new learning and co-learning that has the potential to be embedded in teachers' professional needs and can contribute to changes in their knowledge, skills, and practices. Interestingly, in the absence of formal professional development opportunities, new teachers in our study learned to be proactive and more readily collaborate with others when facing problems, thus benefitting from informal resources for learning and development. In their systematic review of 74 studies on teachers' informal learning, Kyndt et al. (2016) found that beginning teachers learn more through observing colleagues and interacting with their informal mentors. As Little (2002) argued, for collaboration to enable teacher learning and innovations in teacher practice, opportunities to talk about teaching and learning ought to be evident in the ongoing encounters among teachers.

Self-learning. Self-learning was another developmental venue that enhanced our participants' effectiveness as teachers. When confronted with difficult situations, the opportunity to step back and mentally prepare for the next challenge had helped some novice teachers in our sample to develop and improve. Practitioners usually engage in reflection as a means of problem solving, understanding the nature of teaching, and uncovering personal values and beliefs (Lee, 2005); when teachers reflect, they learn from their experiences, build new knowledge, and develop professionally. Reflection permits teachers to start from their own individual experiences and perspectives, to consider these in their contextual variations, and to draw upon the theoretical, professional strategies that they have encountered or plan to explore (Sellars, 2012). However, the alarming finding was that some teachers could not find dedicated time for adequate reflection on their practice because they were just trying to survive from day to day. We understand that such lack of time might be related to the teacher's busy schedule, but it might also be related to how well teachers were able to manage their time. Planning ahead was described as an effective strategy by some, and yet, a healthy balance is needed for adequate time 
to plan and to reflect. Sellars (2012) posited that educational change that teachers have the skills and opportunities to effect is only as reliable and proficient as the teachers' individual capacities for reflective practice and the development of self-knowledge.

Proactive mindset was another strategy that allowed early career teachers to plan ahead and be flexible. Generally speaking, the ability to develop a growth mindset, rather than a fixed mindset, is viewed as a core element that helps people develop and excel (Dweck, 2006). As development comes with experience in classroom, reflection then becomes a continuous process that does not end by analyzing the event effectively, but rather continues to answer the "what is next" question. The next steps for new teachers entailed independent work, engaging in activities and groups, volunteering, attending workshops, acquiring knowledge through reading and pursuing further qualifications. These self-learning strategies demonstrated our teachers' enthusiasm and eagerness to grow professionally (Kwakman, 2003). For self-learning to be effective, however, the appropriate professional setting must exist in schools so that teachers are able to engage in reflection and inquiry about their practices (Ostorga, 2006).

Collegial school climate. Finally, our findings confirmed that positive school climatewhich is largely based on the quality of relationships at school, on strong interdependence and connections among stakeholders, and on trust and shared values-is of significant impact on new teachers' development (Castro, Kelly, \& Shih, 2010; Gardiner, 2012; Hoy, Smith, \& Sweetland, 2002; Perry \& Hayes, 2011). School climate is the quality and character of school life based on patterns of people's experiences of school life and reflects norms, goals, values, interpersonal relationships, teaching and learning practices, and organizational structures (Cohen, McCabe, Michelli, \& Pickeral, 2009, p. 184).

In our study, two dimensions of relationships with colleagues were evident in the novices' experiences, with experienced teachers and with other new teachers, each with specific advantages. Experienced teachers offered them the necessary support and advice, especially in challenging professional situations and when they needed space and the opportunities to share their frustrations. The second segment, relationships with other new teachers in their schools, seemed to offer our participants the emotional support they had needed. Effective interpersonal relationships amongst colleagues have been found to lead to greater satisfaction, ability to develop professionally, more effective and confident decision making, and increased sense of belonging and efficacy (Grodsky \& Gamoran, 2003). Overall, good relationships with colleagues enabled new teachers to operate within the culture of open access to knowledge and expertise, collective problem solving, and trusting school climate, particularly reflected in their courage to share their frustrations (Bryk \& Schneider, 2002; Tschannen-Moran \& Hoy, 2001).

Two other relational dimensions emerged from the narratives, namely relationships with students and with school administrators. Having good relationships with students was of significant benefit to those new teachers who measured their effectiveness in terms of creating a positive impact. Importance of building positive teacher-student relationships was found strongly related to effective classroom management and instructional quality of beginning teachers (Kwok, 2017). Similarly, effective teachers have been described as "those who develop relationships with students that are emotionally close, safe, and trusting, who provide access to instrumental help, and who foster a more general ethos of community and caring in classrooms" (Wentzel, 2012, p. 19). Positive relationships with administrations facilitated novices' development, increased their efficacy, and enhanced their capacity to deal with parents. 
Researchers found that principals' personal interactions with individual teachers tended to promote a healthy school climate and student outcomes, whereas unsupportive or negative interactions may lead to teachers' dissatisfaction, attrition, or move to a different school (Bickmore \& Bickmore, 2010; Guarino et al., 2006; Scherff, 2008). In addition, Moolenaar et al. (2012) noted the relational reciprocity in which principals maximize teachers' skills and knowledge, and teachers in return seek out their principal more often for work related and personal advice, and thus benefit from their knowledge, resources, and expertise.

Overall, our findings provided evidence for two of the four essential dimensions of school climate evident from extant research: relationships and teaching and learning (Cohen et al., 2009, p. 184). Within the relationships dimension, our participants highlighted the need for a mutual support and ongoing communication in the school community and collaboration subdimension, and positive student, parent, teacher, and administrator interpersonal dynamics within the morale and connectedness sub-dimensions. In doing so, they also emphasized support for learning and continual improvement in the professional development sub-dimension and administrative accessibility, support, and honoring of people in the leadership sub-dimension within the teaching and learning dimension of school climate. On the contrary, our findings confirmed that beginning teachers' learning may be hindered by unsupportive climate or limited collegial relationships, leaving teachers with the feeling that they lack the power to change those conditions (Flores, 2004).

\section{Research Implications}

A number of explicit implications might be generated from these findings for individual teachers, school leaders and organizations. There are a number of insights that warrant the attention of early career teachers, their peers, and their school leaders, in particular. While neither generalizable nor contextually prescriptive, the findings indicated highlight and reinforce a number of requisites new teachers need that, if satisfied, are likely to enhance their thriving and result in less attrition and improved circumstances for everyone. These insights will resonate with early career teachers and focus on those who mentor them, either directly or as administrators. We think that an awareness of these expressions of needs by school leaders and teacher mentors will result in an affirmation of any and all initiatives designed for the sake of teacher wellbeing and the facilitation of beginning teacher success.

School leaders will see themselves implicated in the clear messaging of this small sample of teachers who have said that their decisions to stay in or to leave the profession were complex but affected by a number of intrinsic and extrinsic factors. To be quite clear, the positive, omnidirectional affirmation and support of peers, mentors, and administration are critical factors for beginning teacher retention. Teacher-peers and school leaders do make a positive difference. Any efforts (i.e., sharing resources or providing timely emotional support by listening) offered by peers and school administrators are likely to encourage new teachers' confidence, positive mindsets, and socialization. As well, careful and timely efforts to bolster teachers' adaptive capacities for the challenges of particular contexts are important. Well-fitted mentors, needsensitive leaders, and the positive qualities of interpersonal relationships are factors that afford and make positive differences for beginning teachers.

We reiterated that when teachers felt supported by their principals, these instances were highly influential in establishing them in positive school cultures and this specific support 
enhanced their perceptions of their own efficacy. The opposite behavior frustrated early career teachers and contributed to their leaving the work of teaching. This research reminds teachers, their peers, their mentors and school leaders that everyone in the constellation of beginning teachers need to remind these new teachers to attend to their self-care plans.

There are findings from this study that reinforce the salience of early career teachers' formal and informal learning from others, of a focus on self-learning, and of efforts to sustain a collegial school climate. Programmatic support through coaching, educating, enabling, organizing, managing, and through counseling are important. As indicated, our participants learned to be proactive and to more readily collaborate with others when facing problems. The provision of safe environments to take proactive and other risks and experiment, issues another set of responses to meeting the needs of neophyte teachers. When confronted with difficult situations, teachers learn from their experiences, build new knowledge, and develop professionally. However, some teachers have difficulties finding dedicated time for adequate reflection and planning. Together with enthusiasm and eagerness, a proactive mindset was seen as crucial to professional growth for new teachers. School administrators may be able to facilitate effective strategies and time for this planning and proactivity. Working in schools where positive relationships with colleagues were encouraged seemed to provide specific advantages; thus, school leaders are encouraged to foster the same. School administrators and experienced teachers can offer new teachers the necessary support and advice, especially in challenging professional situations and when space and opportunities to share frustrations and find trusted emotional support are needed. From this and other cited research, relationships with students and with school administrators have been shown to provide significant benefit for novice teachers' development, their increased efficacy, and their enhanced capacity to deal with parent, student, and workload challenges. Principals will be affirmed in their positive and supportive personal interactions with individual teachers as they seek to co-promote the elements and qualities of a healthy school climate and of enhanced student outcomes.

\section{Conclusion}

Our study invited selected early career teachers from across Canada to talk about the inspirational moments and challenges of their first years of teaching. There was a general collegial sense of sharing for the greater good among the teachers interviewed. As we reflect on the realities of early years teaching and ponder how the outcomes of early teaching can be improved, we see many parallels between our study results and the extant literature. These data open up complexities within the field to be further explored. For example, we see the need to improve the supports for new teachers, to purposefully develop new and existing induction and mentoring programs, and we see a call for a holistic, caring, collegial approach to developing our educational systems. Although we have delimited our discussion to the key insights from teacher narratives that related to attrition, retention, and development, we also noted that some of the more specific findings, such as the significance of positive school climates and the limitations of restrictive provincial policies, require further inquiry.

How these teachers struggled on the paths of retention and attrition behooves further research so that we might better understand about each pathway. In addition to large-scale quantitative studies, longitudinal qualitative studies that commence with participants in their teacher training programs and continue through the first 10 years of their teaching development are needed. Such studies might yield deeper understandings of the transitional phases new 
teachers go through, the critical life moments that impact their development, and the pivotal factors leading to retention, attrition, and development. When teachers who have a rich history of experiences and reflections narrate what they have needed along the way, we are in a much stronger position to support them and their new teacher colleagues in their most critical early years of teaching. 


\section{References}

Achinstein, B. (2006). New teacher and mentor political literacy: Reading, navigating and transforming induction contexts. Teachers and Teaching: Theory and Practice, 12(2), 123-138. doi:10.1080/13450600500467290

Admiraal, W., Kruiter, J., Lockhorst, D., Schenke, W., Sligte, H., Smit, B., . . . de Wit, W. (2016). Affordances of teacher professional learning in secondary schools. Studies in Continuing Education, 38(3), 281-298. doi:10.1080/0158037X.2015.1114469

Andrews, B. D., \& Quinn, R. J. (2004). First-year teaching assignments: A descriptive analysis. The Clearing House, 78(2), 78-83.

Andrews, N., \& Akerson, A. (2012). Mentoring: A university approach. National Teacher Education Journal, 5(1), 29-34.

Anhorn, R. (2008). The profession that eats its young. The Delta Kappa Gamma Bulletin, 74(3), 15-26.

Barrett, S. E., Solomon, R. P., Singer, J., Portelli, J. P., \& Mujuwamariya, D. (2009). The hidden curriculum of a teacher induction program: Ontario teacher educators' perspectives. Canadian Journal of Education, 32(4), 677-702.

Bickmore, S. T., \& Bickmore, D. L. (2010). Revealing the principal's role in the induction process: Novice teachers telling their stories. Journal of School Leadership, 20(4), 445469.

Boreen, J., Johnson, M. K., Niday, D., \& Potts, J. (2009). Mentoring beginning teachers: Guiding, reflecting, coaching (2nd ed.). Portland, ME: Stenhouse Publishers.

Borman, G. D., \& Dowling, N. M. (2008). Teacher attrition and retention: A meta-analytic and narrative review of the research. Review of Educational Research, 78(3), 367-409.

Brindley, R., \& Parker, A. (2010). Transitioning to the classroom: Reflections of second-career teachers during the induction year. Teachers and Teaching, 16(5), 577-594. doi:10.1080/13540602.2010.507967

Brock, B., \& Grady, M. (2006). Developing a teacher induction plan: A guide for school leaders. Thousand Oaks, CA: Corwin.

Brown, K., \& Wynn, S. R. (2009). Finding, supporting, and keeping: The role of the principal in teacher retention issues. Leadership and Policy in Schools, 8(1), 37-63.

Bryk, A., \& Schneider, B. (2002). Trust in schools: A core resource for improvement. New York, NY: Russell Sage Foundation.

Campbell, C. (2017). Developing teachers' professional learning: Canadian evidence and experiences in a world of educational improvement. Canadian Journal of Education, 40(2), 1-33. 
Carbonneau, N., Vallerand, R. J., Fernet, C., \& Guay, F. (2008). The role of passion for teaching in intrapersonal and interpersonal outcomes. Journal of Educational Psychology, 100(4), 977-987. doi:10.1037/a0012545

Castro, A. J., Kelly, J., \& Shih, M. (2010). Resilience strategies for new teachers in high-needs areas. Teaching and Teacher Education, 26(3), 622-629. doi:10.1016/j.tate.2009.09.010

Catapano, S., \& Huisman, S. (2013). Leadership in hard-to-staff schools: Novice teachers as mentors. Mentoring \& Tutoring: Partnership in Learning, 21 (3), 258-271. doi:10.1080/13611267.2013.827833

Certo, J. L. (2005). Support, challenge, and the two-way street: Perceptions of a beginning second grade teacher and her quality mentor. Journal of Early Childhood Teacher Education, 26, 3-21.

Chase, S. E. (2005). Narrative inquiry: Multiple lenses, approaches, voices. In N. K. Denzin \& Y. Lincoln (Eds.), The Sage handbook of qualitative research (3rd ed., pp. 651-679). London, UK: Sage.

Cherian, F., \& Daniel, Y. (2008). Principal leadership in new teacher induction: Becoming agents of change. International Journal of Education Policy and Leadership, 3(2), 1-11.

Cherubini, L., Kitchen, J., \& Hodson, J. (2008). Aboriginal epistemologies and new teacher induction: The context of a bi-epistemic research endeavour. Brock Education, 18, 79-89.

Clandinin, D. J., \& Connelly, F. M. (2000). Narrative inquiry: Experience and story in qualitative research (1st ed.). San Francisco, CA: Jossey-Bass.

Clandinin, D. J., \& Huber, J. (2010). Narrative inquiry. In E. Baker \& B. McGaw (Eds.), International encyclopedia of education (3rd ed., pp. 436-441). Oxford: Elsevier.

Clandinin, D. J., Schaefer, L., Long, J. S., Steeves, P., McKenzie-Robblee, S., Pinnegar, E., . . . Downey, C. A. (2012). Early career teacher attrition: problems, possibilities, potentials. Edmonton, AB: Centre for Research for Teacher Education and Development, University of Alberta.

Clark, R., \& Antonelli, F. (2009). Why teachers leave: Results of an Ontario Survey 2006-08. Toronto, ON: Ontario Teachers' Federation.

Clark, S. K., \& Byrnes, D. (2012). Through the eyes of the novice teacher: Perceptions of mentoring support. Teacher Development, 16(1), 43-54. doi:10.1080/13664530.2012.666935

Cohen, J., McCabe, E. M., Michelli, N. M., \& Pickeral, T. (2009). School climate: Research, policy, practice, and teacher education. Teachers College Record, 111(1), 180-213.

Connelly, F. M., \& Clandinin, D. J. (2006). Narrative inquiry. In J. Green, G. Camilli, \& P. Elmore (Eds.), Handbook of complementary methods in education research (pp. 375-385). Mahwah, NJ: Erlbaum. 
Cooperrider, D. L., \& Whitney, D. (2007). Appreciative Inquiry: A positive revolution in change. In P. Holman \& T. Devane (Eds.), The change handbook. San Franscisco, CA: BerrettKoehler.

Craig, C. J. (2014). From stories of staying to stories of leaving: A US beginning teacher's experience. Journal of Curriculum Studies, 46(1), 81-115. doi:10.1080/00220272.2013.797504

Darling-Hammond, L. (2006). Constructing 21st-century teacher education. Journal of Teacher Education Policy Analysis Archives, 57(3), 300-314.

Darling-Hammond, L., \& Richardson, N. (2009). Teacher learning: What matters? Educational Leadership, 66, 46-53.

Dempsey, I., \& Christenson-Foggett, J. (2011). External mentoring support for early career special education teachers. Australasian Journal of Special Education, 35(1), 61-71. doi:10.1375/ajse.35.1.61

Donne, V., \& Lin, F.-Y. (2013). Special education teacher induction: The wiki way. The Clearing House, 86(2), 43-47. doi:10.1080/00098655.2012.735279

Dweck, C. S. (2006). Mindset: The new psychology of success. New York, NY: Ballantine Books.

Eberhard, J., Reinhardt-Mondragon, P., \& Stottlemyer, B. (2000). Strategies for new teacher retention: Creating a climate of authentic professional development for teachers with three or less years of experience. Corpus Christi, TX: The South Texas Research and Development Center, Texas A \& M University.

Elfers, A. M., Plecki, M. L., \& Knapp, M. S. (2006). Teacher mobility: Looking more closely at "the movers" within a state system. Peabody Journal of Education, 81(3), 94-127.

Ewart, G. (2009). Retention of new teachers in minority French and French immersion programs in Manitoba. Canadian Journal of Education, 32(3), 473-507.

Ewing, R., \& Smith, D. (2003). Retaining quality early career teachers in the profession. English Teaching: Practice and Critique, 2(1), 15-32.

Fantilli, R. D., \& McDougall, D. E. (2009). A study of novice teachers: Challenges and supports in the first years. Teaching and Teacher Education, 25(6), 814-825. doi:10.1016/j.tate.2009.02.021

Farrell, T. S. C. (2012). Novice-service language teacher development: Bridging the gap between preservice and in-service education and development. TESOL Quarterly, 46(3), 435-449.

Fenwick, A. (2011). The first three years: Experiences of early career teachers. Teachers and Teaching, 17(3), 325-343. doi:10.1080/13540602.2011.554707

Flores, M. A. (2004). The impact of school culture and leadership on new teachers' learning in the workplace. International Journal of Leadership in Education, 7(4), 297-318. doi:10.1080/1360312042000226918 
Frels, R. K., Zientek, L. R., \& Onwuegbuzie, A. J. (2013). Differences of mentoring experiences across grade span among principals, mentors, and mentees. Mentoring \& Tutoring: Partnership in Learning, 21(1), 28-58. doi:10.1080/13611267.2013.784058

Friedrichsen, P., Chval, K. B., \& Teuscher, D. (2007). Strategies and sources of support for beginning teachers of science and mathematics. School Science and Mathematics, 107(5), $169-181$.

Gardiner, W. (2012). Coaches' and new urban teachers' perceptions of induction coaching: Time, trust, and accelerated learning curves. The Teacher Educator, 47(3), 195-215. doi:10.1080/08878730.2012.685797

Glazerman, S., Isenberg, E., Dolfin, S., Bleeker, M., Johnson, A., Grider, M., \& Jacobus, M. (2010). Impacts of comprehensive teacher induction: Final results from a randomized controlled study (NCEE 2010-4027). Washington, DC: National Center for Education Evaluation and Regional Assistance, Institute of Education Sciences, U.S. Department of Education.

Grodsky, E., \& Gamoran, A. (2003). The relationship between professional development and professional community in American schools. School Effectiveness and School Improvement, 14(1), 1-29.

Guardino, C. A., \& Fullerton, E. (2010). Changing behaviors by changing the classroom environment. Teaching Exceptional Children, 42(6), 8-13.

Guarino, C. M., Santibañez, L., \& Daley, G. A. (2006). Teacher recruitment and retention: A review of the recent empirical literature. Review of Educational Research, 76(2), 173-208. doi:10.3102/00346543076002173

Harris, B. (2015). Retaining new teachers: How do I support and develop new teachers? Alexandria, VA: ASCD.

Harrison, J., Dymoke, S., \& Pell, T. (2006). Mentoring beginning teachers in secondary schools: An analysis of practice. Teaching and Teacher Education, 22(8), 1055-1067. doi:10.1016/j.tate.2006.04.021

Hatton, N., \& Smith, D. (1995). Reflection in teacher education: Towards definition and implementation. Teaching and Teacher Education, 11(1), 33-49.

Henry, G. T., Bastian, K. C., \& Fortner, C. K. (2011). Stayers and leavers: Early career teacher effectiveness and attrition. Educational Researcher, 40(6), 271-280.

Hobson, A. J., Ashby, P., Malderez, A., \& Tomlinson, P. D. (2009). Mentoring beginning teachers: What we know and what we don't. Teaching and Teacher Education, 25(1), 207-216. doi:10.1016/j.tate.2008.09.001

Howe, E. R. (2006). Exemplary teacher induction: An international review. Educational Philosophy and Theory, 38(3), 287-297. 
Hoy, W., Smith, P. A., \& Sweetland, S. R. (2002). The development of the organizational climate index for high schools: Its measure and relationship to faculty trust. The High School Journal, 86(2), 38-49.

Ingersoll, R. M., \& Strong, M. (2011). The impact of induction and mentoring programs for beginning teachers: A critical review of the research. Review of Education Research, 81(2), 201-233.

Johnson, S. M., \& Kardos, S. M. (2002). Keeping new teachers in mind. Educational Leadership, $59(6), 12-16$.

Jones, M. (2002). Qualified to become good teachers: A case study of ten newly qualified teachers during their year of induction. Journal of In-Service Education, 28(3), 509-526.

Jones, M. (2003). Reconciling personal and professional values and beliefs with the reality of teaching: Findings from an evaluative study of ten newly qualified teachers during their year of induction. Teacher Development, 7(3), 385-402.

Joseph, R. (2000). Stress free teaching: A practical guide to tackling stress in teaching, lecturing and tutoring. London, UK: Routledge.

Karsenti, T., \& Collin, S. (2013). Why are new teachers leaving the profession? Results of a Canada-wide survey. Education, 3(3), 141-149. doi:10.5923/j.edu.20130303.01

Karsenti, T., Collin, S., Villeneuve, S., Dumouchel, G., \& Roy, N. (2008). Why are new French immersion and French as a second language teachers leaving the profession? Results of a Canada-wide survey. Ottawa, ON: Canadian Association of Immersion Teachers.

Kauffman, D., Johnson, S. M., Kardos, S. M., Liu, E., \& Peske, H. G. (2002). "Lost at sea": New teachers' experiences with curriculum and assessment. Teachers College Record, 104(2), 273-300.

Knowles, M. S., Holton, E. F., \& Swanson, R. A. (2015). The adult learner: The definitive classic in adult education and human resource development (Vol. 8). Abingdon, UK: Routledge.

Kochan, F. K., \& Trimble, S. B. (2000). From mentoring to co-mentoring: Establishing collaborative relationships. Theory into Practice, 39(1), 20-28.

Kwakman, K. (2003). Factors affecting teachers' participation in professional learning activities. Teaching and Teacher Education, 19(2), 149-170. doi:10.1016/S0742-051X(02)00101-4

Kwok, A. (2017). Relationships between instructional quality and classroom management for beginning urban teachers. Educational Researcher, 46(7), 355-365. doi:10.3102/0013189X17726727

Kyndt, E., Gijbels, D., Grosemans, I., \& Donche, V. (2016). Teachers' everyday professional development: Mapping informal learning activities, antecedents, and learning outcomes. Review of Educational Research, 86(4), 1111-1150. doi:10.3102/0034654315627864

Kyriacou, C., \& Kunc, R. (2007). Beginning teachers' expectations of teaching. Teaching and Teacher Education, 23(8), 1246-1257. doi:10.1016/j.tate.2006.06.002 
Lankau, M. J., \& Scandura, T. A. (2002). An investigation of personal learning in mentoring relationships: Content, antecedents, and consequences. Academy of Management Journal, 45(4), 779-790.

Le Maistre, C., Boudreau, S., \& Paré, A. (2006). Mentor or evaluator? Assisting and assessing newcomers to the professions. Journal of Workplace Learning, 18(6), 344-354. doi:10.1108/13665620610682071

Lee, H.-J. (2005). Understanding and assessing preservice teachers' reflective thinking. Teaching and Teacher Education, 21(6), 699-715. doi:10.1016/j.tate.2005.05.007

Lichtman, M. (2010). Qualitative research in education: A user's guide. Thousand Oaks, CA: Sage.

Liston, D., Whitcomb, J., \& Borko, H. (2006). Too little or too much: Teacher preparation in the first years of teaching. Journal of Teacher Education, 57(4), 351-358.

Little, J. W. (2002). Locating learning in teachers' communities of practice: Opening up problems of analysis in records of everyday work. Teaching and Teacher Education, 18(8), 917-946. doi:10.1016/S0742-051X(02)00052-5

Long, J. S., McKenzie-Robblee, S., Schaefer, L., Steeves, P., Wnuk, S., Pinnegar, E., \& Clandinin, D. J. (2012). Literature review on induction and mentoring related to early career teacher attrition and retention. Mentoring \& Tutoring: Partnership in Learning, 20(1), 7-26. doi:10.1080/13611267.2012.645598

Lovett, S., \& Cameron, M. (2011). Schools as professional learning communities for earlycareer teachers: How do Early Career teachers rate them? Teacher Development, 15(1), 87-104. doi:10.1080/13664530.2011.555226

Lovett, S., \& Davey, R. (2009). Being a secondary English teacher in New Zealand: Complex realities in the first 18 months. Professional Development in Education, 35, 547-566.

MacMillan, J. H., \& Schumacher, S. (2006). Research in education: Evidence-based inquiry. Boston, IL: Pearson.

Moir, E., Barlin, D., Gless, J., \& Miles, J. (2009). New teacher mentoring: Hopes and promise for improving teacher effectiveness. Cambridge, MA: Harvard Education Press.

Moolenaar, N. M., Daly, A. J., \& Sleegers, P. J. (2012). Exploring patterns of interpersonal relationships among teachers. In T. Wubbels, P. den Brok, J. van Tartwijk, \& J. Levy (Eds.), Interpersonal relationships in education (pp. 87-101). Rotterdam, NL: Sense.

Nasser-Abu Alhija, F., \& Fresko, B. (2010). Socialization of new teachers: Does induction matter? Teaching and Teacher Education, 26(8), 1592-1597. doi:10.1016/j.tate.2010.06.010

Nieto, S. (2003). What keeps teachers going? New York, NY: Teachers College Press.

Ostorga, A. N. (2006). Developing teachers who are reflective practitioners: A complex process. Issues in Teacher Education, 15(2), 5-20. 
Patterson, M. (2005). Hazed! Educational Leadership, 62(8), 20-23.

Perry, B., \& Hayes, K. (2011). The effect of a new teacher induction program on new teachers reported teacher goals for excellence, mobility, and retention rates. International Journal of Educational Leadership Preparation, 6(1), 1-12.

Portner, H. (2008). Mentoring new teachers (3rd ed.). Thousand Oaks, CA: Corwin Press, Inc.

Razer, M., \& Friedman, V. J. (2017). From exclusion to excellence: Building restorative relationships to create inclusive schools. New York, NY: Springer.

Richter, D., Kunter, M., Klusmann, U., Lüdtke, O., \& Baumert, J. (2011). Professional development across the teaching career: Teachers' uptake of formal and informal learning opportunities. Teaching and Teacher Education, 27(1), 116-126. doi:10.1016/j.tate.2010.07.008

Rinke, C. R. (2008). Understanding teachers' careers: Linking professional life to professional path. Educational Research Review, 3(1), 1-13.

Rivkin, S. G., Hanushek, E. A., \& Kain, J. F. (2005). Teachers, schools, and academic achievement. Princeton, NJ: Econometrica.

Ross, J., \& Gray, P. (2006). School leadership and student achievement: The mediating effects of teacher beliefs. Canadian Journal of Education, 29(3), 798-822.

Schaefer, L. (2013). Beginning teacher attrition: A question of identity making and identity shifting. Teachers and Teaching, 19(3), 260-274. doi:10.1080/13540602.2012.754159

Schaefer, L., Downey, C. A., \& Clandinin, D. J. (2014). Shifting from stories to live by to stories to leave by: Early career teacher attrition. Teacher Education Quarterly, 41(1), 9-27.

Schaefer, L., Long, J. S., \& Clandinin, D. J. (2012). Questioning the research on early career teacher attrition and retention. Alberta Journal of Educational Research, 58(1), 106-121.

Scherff, L. (2008). Disavowed: The stories of two novice teachers. Teaching and Teacher Education, 24(5), 1317-1332.

Schuck, S., Aubusson, P., Buchanan, J., \& Russell, T. (2012). Beginning teaching: Stories from the classroom. Dordrecht, NL: Springer.

Schuck, S., Brady, L., \& Griffin, J. (2005). Initiation and rites of passage: Learning the school culture. Change: Transformations in Education, 8(1), 43-54.

Sellars, M. (2012). Teachers and change: The role of reflective practice. Procedia - Social and Behavioral Sciences, 55, 461-469. doi:10.1016/j.sbspro.2012.09.525

Sprinthall, N. A., Heiman, A. J., \& Thies-Sprinthall, L. (1996). Teacher professional development. In J. Sikula (Ed.), Handbook of research on teacher education (2nd ed., pp. 666-703). New York, NY: Macmillan.

Swanson, P. B. (2012). Second/foreign language teacher efficacy and its relationship to professional attrition. Canadian Modern Language Review, 68(1), 78-101. 
Tillman, L. C. (2005). Mentoring new teachers: Implications for leadership practice in an urban school. Educational Administration Quarterly, 41(4), 609-629. doi:10.1177/0013161x04274272

Towers, J. (2012). Administrative supports and curricular challenges: New teachers enacting and sustaining inquiry in schools. Canadian Journal of Education, 35(1), 259-278.

Tschannen-Moran, M. (2009). Fostering teacher professionalism in schools: The role of leadership orientation and trust. Education Administration Quarterly, 45(2), 217-247.

Tschannen-Moran, M., \& Hoy, A. W. (2001). Teacher efficacy: Capturing an elusive construct. Teaching and Teacher Education, 17(7), 783-805.

Tschannen-Moran, M., \& McMaster, P. (2009). Sources of self-efficacy: Four professional development formats and their relationship to self-efficacy and implementation of a new teaching strategy. The Elementary School Journal, 110(2), 228-248.

Tschannen-Moran, M., \& Tschannen-Moran, B. (2011). Taking a strengths-based focus improves school climate. Journal of School Leadership, 21(2), 422-448.

Valeo, A., \& Faez, F. (2013). Career development and professional attrition of novice ESL teachers of adults. TESL Canada Journal, 31(1), 1.

Van Manen, M. (1997). Researching lived experience: Human science for an action sensitive pedagogy. London, ON: Althouse Press.

Wechsler, M. E., Caspary, K., \& Humphrey, D. C. (2008). State-funded induction and mentoring programs in Illinois: Findings from the original ten programs Menlo Park, CA: SRI International.

Wentzel, K. R. (2012). Teacher-student relationships and adolescent competence at school. In T. Wubbels, P. den Brok, J. van Tartwijk, \& J. Levy (Eds.), Interpersonal relationships in education (pp. 19-35). Rotterdam, NL: Sense.

Whisnant, E., Elliott, K., \& Pynchon, S. (2005). A review of literature on beginning teacher induction. Tacoma, WA: Center for Strengthening the Teaching Profession.

Wong, H. K. (2004). Induction programs that keep new teachers teaching and improving. NASSP Bulletin, 88(638), 41-58.

Wood, A. L., \& Stanulis, R. N. (2009). Quality teacher induction: "Fourth-wave" (1997-2006) induction programs. The New Educator, 5, 1-23.

Wynn, S. R., Carboni, L. W., \& Patall, E. A. (2007). Beginning teachers' perceptions of mentoring, climate, and leadership: Promoting retention through a learning communities perspective. Leadership and Policy in Schools, 6(3), 209-229.

doi:10.1080/15700760701263790 